\title{
Central Issues of Research
}

\subsection{EU Competition Law - A Paradox within EU Law}

Bork's seminal book The Antitrust Paradox: A Policy at War with Itself started by pointing out the main features of American anti-trust. First of all, American anti-trust was a largely unknown policy despite being ubiquitous due to the "elaborate deployments of governmental force in areas of life still thought committed primarily to private choice and initiative". ${ }^{1}$ Second, American antitrust was popular as very little intellectual and almost no political opposition to its features was shown. Lastly, American anti-trust appeared to Bork exportable as jurisdictions in Europe and Asia followed the American example. ${ }^{2}$ At the same time, anti-trust was a policy at war with itself because certain antitrust doctrines preserved competition, while others suppressed it. ${ }^{3}$ This policy produced inconsistent case-law because the courts could not clearly spell the purpose of anti-trust laws.

The contours of European competition law are both similar and different from those described by Bork. They could be summarized as follows:

(1) The congenital nature of EU competition law - EU competition law was created and developed in the same time as the legal context that generated it, that is EU law. It therefore borrows some of the features of EU law, while remaining reminiscent of its ancestors, the American anti-trust law and French and German administrative law.

A seasoned writer about the European Union, Deirdre Curtin wrote that,

as an object of research, it is certainly true to say that the EU is unidentified and travels at great speed. The EU is largely unidentified in that it escapes the conventional labels such as nation, state, empire, region, federation. Yet it possesses elements of several of these categorizations (international organizations, state, political system, etc.). The speed of institutional change is undeniable; from a weak advisory parliamentary assembly to a more powerful European Parliament with co-legislative

1 Bork, Robert H. The Antitrust Paradox: A Policy at War with Itself. New York: The Free Press, 1993, p. 2.

2 Bork, op. cit.

3 Bork, op. cit., p. 7 . 
rights; from a weak court to a strong court, a court that can for example, rule on issues that would appear purely national. ${ }^{4}$

The institutional change within the European Union has been described using both fluid and static perspectives. Lord Denning referred to the EU as an incoming tide, other authors viewed it as a day-by-day, brick-by-brick construction. ${ }^{56}$

While important parts of EU law bathe under the sun of constant transformation, EU competition law remained adamantly resistant to change, its substance and procedure have suffered very little alteration over the years. Competition policy was at the heart of the European integration project, yet only three regulations and two implementing regulations have been adopted to provide guidance for this important field. Also, since the beginning, the great majority of legal rules handling the enforcement of competition law on the European market have been and remain soft law rules.

In addition, given the importance of European competition law experience, one might expect that experience to have been thoroughly studied and its story well told. However, the opposite appears to be true, as only small segments and limited aspects of European competition policy have been described at all. Gerber highlighted that, "as a result, both scholarly and public images of these experience are fundamentally and dangerously flawed. Ideologies, national and linguistic boundaries and sheer ignorance have combined to generate images that are filled with half-truths, non-truths and distortions".7

(2) Politization of separation of powers in EU competition law enforcementAd Geelhoed - an Advocate-General of the CJEU - has argued that EU law has mainly been, until recently, public economic law "aimed at the establishment and proper functioning of the internal market" and that EU economic law was "characterized not so much by ethical preferences, but by choices of a more instrumental nature". ${ }^{8}$ This initial arrangement had deep constitutional

4 Curtin, Deirdre. The Executive Power of the European Union: Law, Practices and the Living Constitution. Oxford: Oxford University Press, 20o9, p. 5.

5 HP Bulmer Ltd $v$ J Bollinger SA [1974] 2 WLR 202.

6 De Witte, Bruno. "The pillar structure and the nature of the European Union: Greek temple or French gothic cathedral?" The European Union after Amsterdam: A Legal Analysis. Eds. T. Heukels, N. Blokker and M. Brus. The Hague: Kluver Law International, 1998, pp. 51-68.

7 Gerber, David J. Law and Competition in Twentieth Century Europe: Protecting Prometheus. Oxford: Oxford University Press, 1998, p. 2.

8 Geelhoed, Ad. "The expanding jurisdiction of the EU Court of Justice." The EU Constitution:The Best Way Forward. Eds. D. Curtin, A.E. Kellerman and S. Blockmans. The Hague: TMC Asser Press, 2005, p. 403. 
consequences. Advocate General Shapston highlighted in her opinion in $K M E$ Germany and Others $v$ Commission that

EU competition law is shaped by the interplay between the Commission, as investigator, prosecutor, decision-maker, and the adjudicator, providing a measure of external control. However, the case-law has never clarified the exact meaning, scope of rationale of the margin of discretion accorded to the Commission, having regard to the institutional balance between the two. ${ }^{9}$

This remains one of the most important critiques raised against EU competition law both by academics and practitioners. Except for the conflict of interests that it raises, considerable interdependence of procedural and substantive law results from the fact that the Commission acts both as a decision-making body and as a party. More precisely, in EU competition law, substantive rules contain procedural standards and a plethora of procedural rules comprise substantive rules. ${ }^{10}$

Indeed, the current system of enforcement of EU competition law consists of two layers, as described in Figure 4 below: An administrative authority - the European Commission - which assumes the functions of investigator, prosecutor, and decision-maker, and a judicial authority - the General Court (GC) or the Court of Justice of the European Union (CJEU) - which holds limited authority over the review of legality of the Commission's decision and unlimited authority over the review of fines. The second, judicial, layer of the enforcement system is triggered only when the affected parties contest the Commission's decision. Otherwise, EU competition law enforcement involves only the first, administrative layer.

In addition, as Figure 5 below shows, the decisions adopted by the EU Commission in competition law cases are prepared by the bureaucratic branch of the Commission - the Directorate-General for Competition (DG COMP), assisted by other DG s - and are adopted by its political branch - the College of Commissioners.

Presidents of the US have occasionally been involved in shaping US antitrust law by establishing the agendas of US anti-trust enforcement agencies, by stuffing them with pro-bigness or anti-bigness champions and by initiating "big cases meant to demonstrate the superiority of government power to

9 Opinion of Advocate General, C-272/o9 P, KME Germany and Others v Commission, ECLI:EU:C:2011:63, point 44.

10 Schwarze, op. cit., p. 1174. 


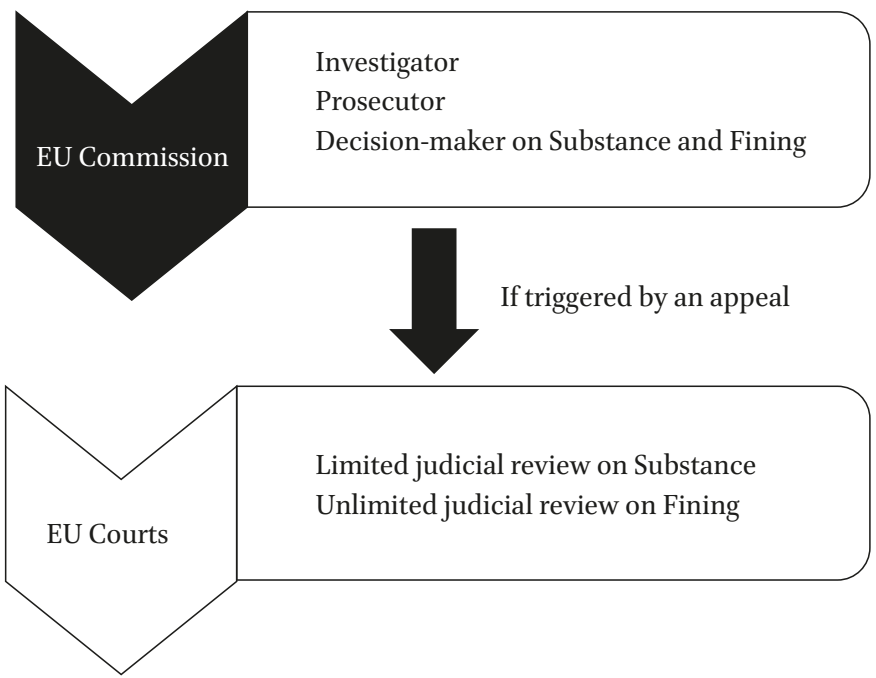

FIGURE 4 The current two-layered enforcement system of EU competition law

Bureaucratic Branch

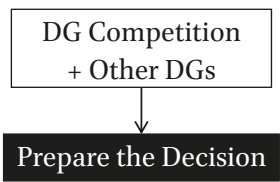

Political Branch

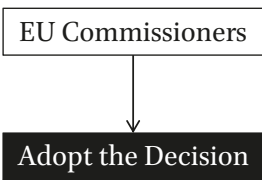

FIGURE 5 Decision-making process for the enforcement of EU competition law

that of powerful private business". "1 Unlike the US, in the EU the participation of the political branch in competition law enforcement is constant. The EU Commissioners for Competition are politicians that are actively participating and deciding the procedural outcomes of competition enforcement proceedings. This blunt involvement of the Union's political forces into its adjudicative activities can be of concern. As Chapters 8 to 12 below will illustrate in detail, the enforcement of competition law raises a few serious concerns about bias that are not answered by the existing safeguards.

The second layer of the EU competition law enforcement system is represented by the judicial branch of the EU. Established in 1952, the European Court of Justice (ECJ) has its seat in Luxembourg and consists currently of two courts: the Court of Justice of the European Union and the General Court (GC). The GC - initially called the Court of First Instance (CFI) - was created

11 Ramsey, op.cit., p. 4. 
in 1988 for the purpose of dealing with disputes involving complex facts. ${ }^{12}$ Competition and civil service litigation were the first types of disputes transferred to the GC. The GC became, thus, to be known as the "Competition court of the European Union". ${ }^{13}$ Brunessen describes the GC as the "Administrative Court of the European Union" because one of its functions is to assess the legality of the decisions adopted by the EU Commission and other institutions, bodies, offices and agencies. ${ }^{14}$ In competition law matters, the GC performs the functions of a first-instance court and the CJEU those of an appeal court.

The CJEU has built its reputation by audaciously asserting legal principles to protect and support the EU as a newly-created legal order. This exercise of audacity often went against the will of the member states or of the general public. At the same time, in the field of competition law, the CJEU has often imposed on itself a limitation that allows the European Commission to receive preferential deferential treatment in cases that concern complex economic and technical evidence. The deferential judicial review is increasingly hard to justify in view of the fact that competition law disputes tend to lack conceptual homogeneity, involve evidentiary hurdles that can border speculation and are prone to serious errors resulting in high costs. ${ }^{15}$

The CJEU has justified deferential judicial review by holding that an institutional balance characterizes the relationships between the EU institutions. ${ }^{16}$ Craig has shown that, as opposed to strict separation of powers, institutional balance "characterized the disposition of legislative and executive power" in the EU from the outset. ${ }^{17}$ In competition law cases, the principle of institutional balance partially accounts for the respect that the CJEU shows for the Commission's margin of discretion and for the ensuing deferential judicial review.

12 88/591/ECSC, EEC, Euratom: Council Decision of 24 October 1988 establishing a Court of First Instance of the European Communities, oJ L 319, 25.11.1988. Date of end of validity: 31/01/2003.

13 Prek, Miro and Silvère Lefèvre. "Competition litigation before the general court: Quality if not quantity?” Common Market Law Review 53 (2016): pp. 65-9o.

14 Brunessen, Bertrand. Le juge de l'Union européenne, juge administratif. Bruxelles: Bruyant, 2015, pp. 169-183.

15 Geradin, Damien and Nicolas Petit. "Judicial Review in European Union Competition Law: A Qualitative and Quantitative Approach." The Role of the Court of Justice of the European Union in Competition Law Cases. Eds. Massimo Merola and Jacques Derennes. Bruxelles: Bruylant, 2012, pp. 32-36.

16 C-9/56, Meroniv High Authority, ECLI:Eu:C:1958:7, paragraph 133.

17 Craig, Paul Philip. "Institutions, Power and Institutional Balance." The Evolution of EU Law. Eds. Paul Craig and Gráinne de Búrca. Oxford: Oxford University Press, 2011, pp. 41-84, p. 41. 
(3) Growing importance of EU Commission-made competition law - Ibáñez Colomo has highlighted that "since its inception, the EU system has revolved, by and large, around expert administrative authorities". ${ }^{18}$ An administration that combines the roles of investigator and decision-maker - as the EU Commission does - may be more prone to opportunistic behaviour than a competition law system centred around courts and private litigation. Ibáñez Colomo adds that

as a result, and somewhat paradoxically, it cannot be excluded that the system eventually becomes less predictable, and also more prone to enforcement errors, than one revolving around generalist courts. Administrative action tainted by opportunism may become less concerned with predictability and consistency and more with advancing the policy objectives of the authority. This attitude may be exacerbated if the review courts show deference to the knowledge of the expert decision-maker. ${ }^{19}$

Prek and Lefèvre - Judge and Legal Secretary at the GC - have noted that a constant decline in the proportion of competition litigation in the judicial activity of the GC can be observed. ${ }^{20}$ This is due, on the one hand, to the success of the commitments procedure and to the CJEU's decision in Alrosa which prevents the GC from engaging into effective judicial review of the commitments decisions adopted by the EU Commission. ${ }^{21}$ They suggest that "the move toward a less confrontational administrative procedure means that there is less likelihood that the undertakings concerned will challenge the outcome of this procedure". ${ }^{22}$

On the other hand, the deployment of the Commission's leniency programme and the settlement procedure create more incentives for the concerned undertakings to cooperate with the EU Commission and to, therefore, avoid litigation. ${ }^{23}$

(4) Specialness of EU competition law - Lawyers have a special interest and loyalty to ideas. They build and defend them in intellectual battles that can last

\footnotetext{
18 Ibáñez Colomo, op. cit.

19 Ibáñez Colomo, op. cit., p. 68.

$20 \quad$ Prek and Lefèvre (2016), op. cit., p. 65.

21 T-170/o6, Alrosa v Commission, ECLI:EU:T:2007:220.

22 Prek and Lefèvre (2016), op. cit., p. 67.

23 Waelbroeck, Denis. Le développement en droit européen de la concurrence des solutions négociées (engagements, clémence, non-contestation des faits et transactions) : Que va-t-il rester aux juges? GCLC Working Paper No. o1/o8, Global Competition Law Centre.
} 
for centuries. However, if Sigmund Freud or Carl Yung wrote this book, they would be concerned with other types of ideas than those which interest lawyers. They would be looking for the beliefs that generate the ideas with which a lawyer operates.

Two such beliefs are of interest at this point. The first is the fact that EU law is special. As Walker explained "EU law was special first and foremost because the European supranational project was an indisputably good cause, a triumph of rationality over passions, of common interest over national insularity, and perhaps most seductively for the legal academic, of law over politics". ${ }^{24}$

The second belief concerns the nature of competition law and seems to dominate the field. This is the idea that competition law is special and that it should, therefore, remain sealed away from exogenous influences. This idea is brought as argument in the majority of papers concerning the subject. It is used to justify every aspect of competition policy in the EU, starting with the constant increase of fines and finishing with the deferential judicial review performed by the EU courts. This dominant intellectual position should unsettle researchers breeding scholarly tolerance and learning to hold opposing views. A lawyer committed to logic might rightfully argue that every field of law is special and that a discussion about competition law being more special is both futile and impossible to argue using logic. Still, as Gerber has noted,

a central feature of European competition law tradition has been the idea that competition law is special and that using law to protect competition moves outside law's normal domain. In this view, competition law is a new type of law which deals with problems for which traditional legal mechanisms are inappropriate, and thus it requires correspondingly non-traditional methods and procedures. ${ }^{25}$

This idea can be traced back to the beginnings of the EU. A review of the first Reports on the Activity of the European Community for Coal and Steel (ECCS) shows that competition policy has been an integral part of the construction of the Common Market. In the early reports, competition policy was the only policy covered, other than the development of the Common Market. ${ }^{26}$

24 Walker (2005), op. cit., p. 5 .

25 Gerber, op. cit., p. 12.

26 European Community for Coal and Steel. "Summary of the Second General Report on the Activities of the Community (April 13, 1953-April 12, 1954)." Bulletin 4 (1954). Available at http://aei.pitt.edu/50821/1/Bo220.pdf accessed on 23 February 2021. 
The first Competition Policy Reports issued by the Commission of the ECCS, European Economic Community (EEC) and European Atomic Energy Community (EAEC) highlight the early emphasis placed on competition policy in somewhat self-aggrandizing statements.

The first Competition Policy Report highlighted that

competition is the best stimulant of economic activity since it guarantees the widest possible freedom of action to all. An active competition policy pursued in accordance with the provisions of the Treaties establishing the Communities makes it easier for the supply and demand structures continually to adjust to technological development. Through the interplay of decentralized decision-making machinery, competition enables enterprises continuously to improve their efficiency, which is the sine qua non for a steady improvement in living standards and employment prospects within the countries of the Community. From this point of view, competition policy is an essential means for satisfying to a great extent the individual and collective needs of our society. ${ }^{27}$ (emphasis added)

A year later, the Commission showed that the general movement towards industrial combination was gathering strength in the Common Market. International concentration of operations in the Common Market showed a marked increase from 1966 to 1970. Consequently, the Summit Conference of Heads of State or of Government of the enlarged Community called for the broadest possible use of Article 235 of the EEC Treaty, which empowered the Council, acting unanimously on Commission proposals, after consulting the Parliament, to take any powers not provided for elsewhere necessary to achieve a specific Community objective. This political decision led the Commission to advise the Council of its intention "to submit, independently of the application of Article 86 to specific cases, proposals designed to introduce a more systematic control of merger operations of a given scale". ${ }^{28}$ From that point on, the Commission's tasks in the field of competition policy have only increased.

The early competition policy reports point to two aspects that will come to define competition policy in the EU. First, the Commission's focus on the development and enforcement of competition policy has not been accompanied by

27 Commission of the European Economic Community. First Report on Competition Policy. Luxembourg: Office for Official Publications of the European Communities, 1972. p. 11.

28 Commission of the European Economic Community. Second Report on Competition Policy. Luxembourg: Office for Official Publications of the European Communities, 1973. pp. 11-12. 
a focus on procedure or due process guarantees for the participants. In fact, the reports describe the Commission as a solitary fighter guarding the Common Market against enterprises that are either unaware that their behaviour is damaging the construction of the Common Market or which willingly behave in a way that hampers the Commission's efforts. Second, the Commission had to work with the member states in order to prevent them from adopting protectionist policies or to lobby them to adopt and implement fully-fledged competition policies.

The belief that competition law is special is widely shared within the academic community. Thus, Graells noted that,

given the specific architecture of the EU competition law enforcement system under Regulation 1/2003, and as long as an effective (arguably, soft or marginal) judicial review mechanism is already available to the undertakings affected by sanctions derived from EU competition law infringements, no significant changes are required in order to make the system comply with Articles 6(1) ECHR. ${ }^{29}$ (emphasis added)

A first mark of specialness identified by the author is the fact that the DG COMP is among the most sophisticated competition law enforcement bodies worldwide, exhibiting a level of expertise that demands respect. Second, the European Commission and the NCA s form part of the European Competition Network (ECN), a body that coordinates and facilitates the exchange of information and best practices. The peer review exercised is a special and beneficial type of control within the ECN. ${ }^{30}$ Also, as stressed by numerous authors, competition law enforcement is far from being a neutral exercise of economic regulation. Rather, it is a policy-oriented enforcement that adheres to incomplete and broad rules and "the final decision to be reached will be conditioned by the ultimate goal the competition authority wants to achieve". 31

(5) Indifference to fundamental rights - European competition law appears to have remained cloistered from the ongoing fundamental rights revolution in

29 Graells, Sanchez. "The EU's Accession to the ECHR and Due Process Rights in EU Competition Law Matters: Nothing New Under the Sun?" The Accession of the EU to the ECHR. Eds. V. Kosta, N. Skoutaris and V. Tzevelekos. Oxford: Hart Publishing, 2014, pp. $255^{-270 .}$

30 Graells, op. cit., pp. 26o-261.

31 Marra, Alessandro, and Alessandro Sarra. "Incomplete Antitrust Laws and Private Actions for Damages." European Journal of Law \& Economics 30 (2010): pp. 111-135. Crane, Daniel A. "Rules Versus Standards in Antitrust Adjudication." Washington and Lee Law Review 64.1 (2007): pp. 49-110. Graells, op. cit., p. 262. 


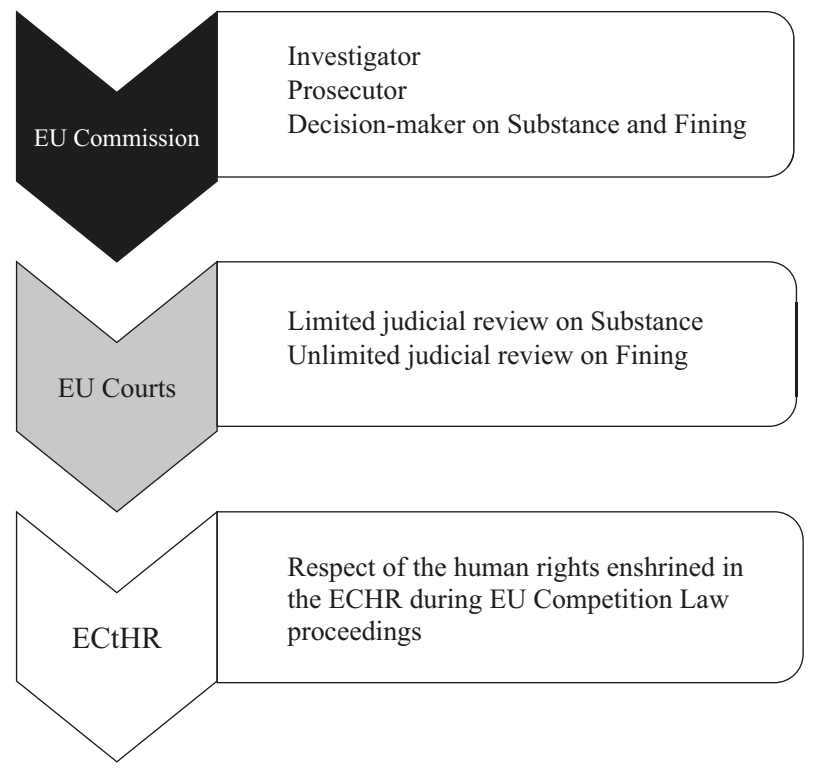

FIGURE 6 The presumptive three-layered enforcement system of EU competition law following the accession of the EU to the ECtHR

the EU. ${ }^{32}$ While the European Union, its institutions and case-law have made strides towards greater legitimacy and accountability, the same cannot be said about competition law, which has remained deaf to the calls of scholars and practitioners. These elements create the environment for a type of exceptionalism that fails to marry easily with democracy.

In light of the features described above, the primary goal of this book is to investigate how the case-law of the ECtHR on Article 6(1) ECHR interacts with the system described above. In view of the accession of the European Union to the ECHR, it had initially been assumed, as Figure 6 below shows, that a successful accession would add a third level of control, tasked with monitoring the respect of fundamental rights during EU competition law proceedings by the ECtHR.

The failed accession of the EU to the ECHR led to the reassessment of the interaction between the case-law on the right to a fair trial and the EU competition law. One way to do this is to presume that the EU will accede to the ECHR and to imagine ways in which the enforcement of EU competition law should be changed to adapt to the conditions prescribed in the case-law of the ECtHR. 
Another way is to assume that the accession of the EU to the ECHR will not be finalized and that the system of enforcement of EU competition law will stay as described in Figure 4 above.

Working with the "no accession" assumption - which at the time of writing stands true - raises important questions about the interaction between the EU and the ECtHR, at least in the field of fundamental rights protection.

Less than $200 \mathrm{~km}$ away from Brussels, another international organization was established in the wake of wwII. The Council of Europe was created in 1949 with the goal of upholding democracy, human rights and rule of law in Europe. The ECHR, an international treaty drawn up within the $\mathrm{CoE}$, was opened for signature in 1950 and entered into force in September 1953.

Under the system established by the ECHR, which prevailed until 31 October 1998, three institutions were entrusted to enforce the obligations undertaken by the contracting states: the European Commission of Human Rights, the ECtHR and the Committee of Ministers of the Council of Europe. ${ }^{33}$

Under the original system, all applications brought by individual applicants or contracting states were subject to preliminary examination by the European Commission of Human Rights. The Commission determined the admissibility of each application and drew up a report expressing a non-binding opinion on the merits of the case. The Commission and/or a government of a state concerned could then decide to refer the case to the European Court of Human Rights for a final, binding adjudication. From 1 November 1998, the European Commission of Human Rights was replaced by a single, full-time ECtHR. The Court's judgments were final and binding for member states. If the Court found a violation of the ECHR, it had no power to quash the decisions of the national authorities. Nevertheless, Article 50 of the Convention mandated the Court to award just satisfaction in the form of financial compensation for pecuniary and non-pecuniary damages and reimbursement of the successful applicants'

33 Grabenwarter, C. European Convention of Human Rights: Commentary. Munchen: C.H. Beck, 2014.

Harris, D., M. O'Boyle, Ed Bates and C.M. Buckley. Law of the European Convention on Human Rights. Oxford: Oxford University Press, 2009.

Keller, H., and A. Stone Sweet, eds. A Europe of Rights: The Impact of the ECHR on National Legal Systems. Oxford: Oxford University Press, 2008. 
costs and expenses. Article 54 ECHR entrusted the Committee of Ministers to supervise the execution of the Court's judgments.

The current book argues that the success of the human rights system generated by the ECHR is due to its design. As Figure 7 suggests, the design of the human rights protection system enforced by the ECtHR had five elements that cumulatively contributed to its success.

(1) Starting with the entry into force of Protocol No. 9 to the ECHR on 1 October 1994, applicants could bring themselves cases before the ECtHR. The right to individual petition is the cornerstone of the Strasbourg human rights system. It allows all citizens and residents of the contracting parties who allege that their human rights have been disrespected, either by an action or a lack of action of a state, to petition the ECtHR after they have exhausted all domestic remedies. The right to individual petition is free of charge. In addition, unlike domestic proceedings, applicants do not need to be represented by a lawyer when lodging an application.

Currently, some 820 million citizens and residents of all member states of the CoE can petition the ECtHR in relation to their grievances. Even if most of the applications lodged at the ECtHR are rejected as inadmissible, it is fair to propose that the applicants are the agenda-setters for the ECtHR. In addition, these applications speak about the state of justice and democracy in their countries of origin. As such, the ECtHR is unmatched as an international tribunal.

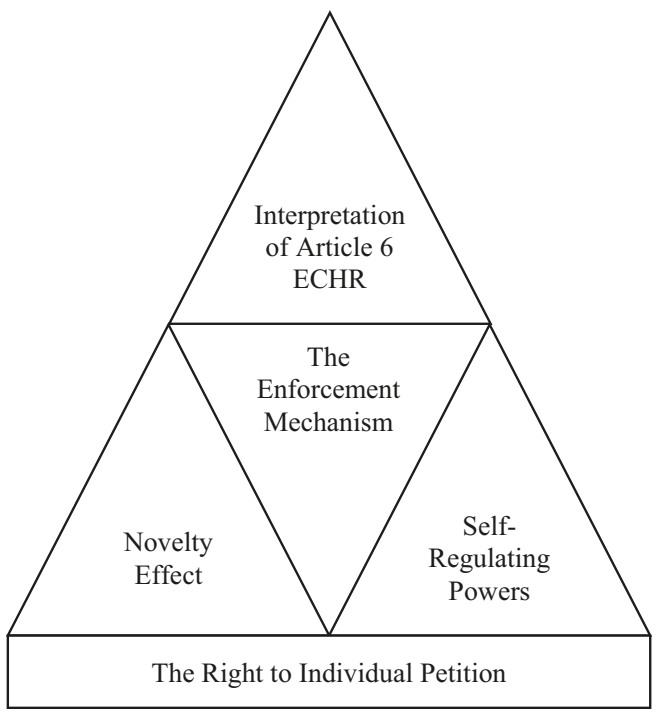

FIGURE 7 The five elements of the human rights system enforced by the ECtHR 
(2) The entry into force of the ECHR and the establishment of the ECtHR have benefitted from a novelty effect. Concerning the relation between the ECHR and the UK, Simpson wrote that "there is no simple answer to the question why the members of the Council of Europe signed the Convention in $195^{\circ}$ and its first protocol in 1952. Nor is there any simple answer to the question what it was that they were signing". ${ }^{34} \mathrm{He}$ explains that the prevailing view was that the Convention would have no significant domestic effects and that "since British law and practice respected human rights this was unlikely to cause any serious domestic problems". 35

These recent works show that, like the EU, the ECtHR also remained unidentified, escaping known labels and denominations by politicians and lawyers. In addition, the ECtHR remained uninteresting to legal scholars for a long time, allowing it to test and hone its concepts and procedural rules.

Unlike the EU, the ECtHR did not grow at great speed. In fact, the ECtHR as an institution has developed slowly. From its creation in 1959 until 1998, when the Court became the only enforcer of the Convention, only 1000 cases were referred to it by the Commission or by governments. ${ }^{36}$ The Court delivered only 837 judgments and adopted 19o decisions rejecting applications. ${ }^{37}$ Article 6(1) ECHR was raised in 455 of these cases and the ECtHR found a violation in 303 of these cases.

(3) The powers of interpretation vested in the ECtHR allowed it to become a self-regulating tribunal. Self-regulation allowed the ECtHR to oscillate between legal imagination and consistent application of its own precepts. It is also self-regulation that enabled the ECtHR to provide innovative solutions to a continent that was undergoing important democratization processes. ${ }^{38}$

(4) The interpretation of Article 6(1) ECHR led to an increasing number of disputes previously considered as belonging to public law to become justiciable. This has led to a progressive enlargement of the ECtHR's jurisdiction. Article 6(1) ECHR provided fertile ground for the ECtHR's quest towards self-regulation because of the central place it occupies in the Convention and because of the

34 Simpson, A.W. Brian. Human Rights and the End of Empire: Britain and the Genesis of the European Convention. Oxford: Oxford University Press, 2001.

35 Simpson, A. W. Brian. "Britain and the European Convention." Cornell International Law Journal 34.3 (2001): article 4.

36 ECtHR. ECtHR Survey - Forty Years of Activity - 1959-1998, p. 4. Available at https://www. echr.coe.int/Documents/Survey_19591998_BIL.pdf accessed on 23 February 2021.

37 ECtHR Survey, quoted above.

38 For a detailed analysis, see Chapter 6 below. 
variety of questions that can be debated around it, such as access to justice, the shape of judicial mechanisms and separation of powers.

(5) The enforcement mechanism put in place by the ECHR is a key element to the design of the Strasbourg human rights system. The member states have undertaken to comply with final judgments of the Court finding violations of the Convention, as well as with Court's decisions taking note of friendly settlements. ${ }^{39}$ The execution of the ECtHR's decisions is supervised by the Committee of Ministers of the Council of Europe, which reunites representatives of the governments of the 47 member states, assisted by the Department for the Execution of Judgments of the ECtHR. The member states enjoy a margin of appreciation regarding the measures that should be taken to remedy a violation of the ECHR. These measures are identified by the member state concerned, under collective supervision of the Committee of Ministers. ${ }^{40}$ In other words, the supervision mechanism empowers the member state that has been found in breach of the Convention to be at the origin of the measure to remedy it. Lastly, the Committee of Ministers is also a collaborative platform, uniting members of the governments of the 47 member states, "trust thereby created is a major prerequisite for constructive cooperation between states in many matters, be they economic, legal or cultural".41

\subsection{ECtHR as a Self-Regulating Tribunal}

The jurisdiction of a national tribunal is usually established by domestic instruments of varying constitutional weight, such as constitutions, procedural codes and ordinary or secondary laws. In addition, national tribunals benefit from theories of legal interpretation which all lawyers study thoroughly during their training. Finally, a two-tiered or three-tiered court system evens the ratione materiae jurisdiction over legal matters, with a Supreme Court harmonizing the approach to all matters of jurisdiction over lower courts. This system ensures that a criminal matter will be settled by a criminal tribunal, following criminal law, instead of landing on the agenda of an arbitration tribunal. By

39 Articles 46 and 39(4) of the European Convention on Human Rights.

40 More information about the supervision process can be found at https://www.coe.int/en/ web/execution/the-supervision-process accessed on 23 February 2021.

41 Council of Europe. Supervision of the Execution of Judgements and Decisions of the European Court of Human Rights: nth Annual Report of the Committee of Ministers 2017, p. 15. Available at https://rm.coe.int/annual-report-2017/168o7afg2b accessed on 23 February 2021. 
the same token, a legal issue concerning the applicability of an investment treaty will be handled by a specialized tribunal created to this end, instead of being settled by a military tribunal.

In other words, at the domestic level, the enquiries, "Who shall judge?", "How should the case be judged?" and "What is justiciable?" - which form the trinity of questions to establish justiciability - are answered by a predictable hierarchy of rules and organs. In case of the ECtHR, answering these questions leads to the understanding that the ECtHR functions as a self-regulating tribunal.

System theorists describe self-organization, resilience and hierarchy, as the most important characteristics of successful systems. ${ }^{42}$ Meadows describe self-organization as the system's "ability to learn, diversify, complexify and evolve". ${ }^{43}$ Open, self-regulating systems are capable of learning in which case "the system performs a reflective knowledge function, interpreting the environment based on its own knowledge". 4

The concept of self-organization or self-regulation applies easily and intuitively to systems existing in the natural world. However, applying this concept to the functioning of an international tribunal requires solid arguments. In the paragraphs below I attempt to build this argument.

For the purposes of the current work, a self-regulating tribunal is one that combines two powers:

- It has competence to decide its own jurisdiction and

- It is able to have an impact on the flow and quality of applications being addressed to it.

The sources of the ECtHR's self-regulatory powers are both (1) internal and (2) external. The internal sources are (a) the design of the jurisdiction of the ECtHR and (b) the interpretation of the right to a fair trial. The external sources concern (a) the cooperation offered by the member states, including their judiciaries, (b) the attitude of the academic community and (c) the zeitgeist. I will analyse these elements one by one.

(1) Internal Sources of the ECtHR's Self-regulatory Powers

(a) The Design of the Jurisdiction of the ECtHR

At the ECtHR, the question "Who shall judge?" is answered in Article $19 \mathrm{ECHR}$ by stipulating that "to ensure the observance of the engagements undertaken by the High Contracting Parties in the Convention and the Protocols thereto,

\footnotetext{
42 Meadows, op. cit., p. 75.

43 Meadows, op. cit., p. 79.

44 Mele, Cristina, Jacqueline Pels and Francesco Polese. "A Brief Review of Systems Theories and Their Managerial Applications." Service Science 2.1/2 (2010): pp. 126-135, p. 128.
} 
there shall be set up a European Court of Human Rights (...). It shall function on a permanent basis". Articles 20-23 continue to answer the same question by describing the criteria for office, election and dismissal of judges.

The answer to the question "How the case should be judged?" is found in the provisions that prescribe that cases can only be decided by a single judge, a committee, a chamber and the Grand Chamber. ${ }^{45}$

The question - "What is justiciable?" - finds an interesting answer in the ECHR. Article 32(1) ECHR provides that "the jurisdiction of the Court shall extend to all matters concerning the interpretation and application of the Convention and the Protocols thereto which are referred to it as provided in Articles 33, 34, 46 and 47".

The jurisdiction of the ECtHR will be shaped, first of all, by an application being lodged by "any person, non-governmental organisation or group of individuals claiming to be the victim of a violation by one of the High Contracting Parties of the rights set forth in the Convention or the Protocols thereto". 46

Second, the jurisdiction of the ECtHR will be shaped by the admissibility criteria enounced in Article 35 ECHR:

1. The Court may only deal with the matter after all domestic remedies have been exhausted, according to the generally recognised rules of international law, and within a period of six months from the date on which the final decision was taken.

2. The Court shall not deal with any application submitted under Article 34 that (a) is anonymous; or (b) is substantially the same as a matter that has already been examined by the Court or has already been submitted to another procedure of international investigation or settlement and contains no relevant new information.

The Court shall declare inadmissible any individual application submitted under Article 34 if it considers that:

(a) the application is incompatible with the provisions of the Convention or the Protocols thereto, manifestly ill-founded, or an abuse of the right of individual application; or

(b) the applicant has not suffered a significant disadvantage, unless respect for human rights as defined in the Convention and the

45 Articles 26, 27 and 28 of the European Convention on Human Rights.

46 Article 34 of the European Convention on Human Rights. 
Protocols thereto requires an examination of the application on the merits and provided that no case may be rejected on this ground which has not been duly considered by a domestic tribunal.

Lastly, Article 32(2) ECHR adds the most important ingredient for selfregulation. This provision stipulates that "in the event of dispute as to whether the Court has jurisdiction, the Court shall decide". In other words, in the event of an application being lodged at the ECtHR alleging a violation of the ECHR, an allegation that is disputed by the member state against whom the application is lodged, the ECtHR has the final say about its own jurisdiction over the case.

In addition, the rules of the ECtHR are adopted by the Court itself, with no apparent external input. ${ }^{47}$

The Interpretation of the Right to a Fair Trial

The second internal element that has allowed the ECtHR to become a selfregulating tribunal is its case-law on the right to a fair trial. This provision is enshrined in Article 6(1) ECHR and appears to have been the main engine for expanding the jurisdiction of the ECtHR over numerous legal fields for which member states have initially claimed ratione materiae immunity. The case-law on the applicability of Article 6(1) ECHR has been the skeleton on which the ECtHR has built its self-regulation muscle.

There a few reasons for this, the most obvious of all being the need to meet a demand. Article 6(1) ECHR is invoked in almost all cases brought before the ECtHR, either independently, when applicants complain about the functioning of domestic jurisdictions, or in parallel with another provision of the ECHR. An example of the latter would be when applicants complain under Article 3 ECHR about torture, inhuman or degrading treatment and under Article 6(1) ECHR about the impossibility to have their rights under Article 3 ECHR recognized by domestic courts.

In addition, the cases brought under Article 6(1) ECHR are rarely political and attract little sustained attention from the public or the media. Compared to cases concerning the right to life or the right to private life, for example, cases that deal with the applicability of the right to a fair trial to employment disputes or constitutional disputes fascinate the minds of non-lawyers to a much lesser degree. This has provided the ECtHR with a safe, non-conflictual public environment to enlarge its jurisdiction.

47 ECtHR. Rules of Court. Strasbourg: 2008. Available at https://www.echr.coe.int/Documents/ Rules_Court_ENG.pdf accessed on 23 February 2021. 
An exception to this, however, concerns cases in which Article 6(1) ECHR was applied to competition law proceedings. Cases like Menarini attract more attention due to the implications that they could bear for European competition law. ${ }^{48}$

\section{(2) External Sources of the ECtHR's Self-Regulatory Powers}

(a) The Cooperation Offered by the Member States

Turning now to the external factors supporting the ECtHR's self-regulation, it is important to highlight that the success of the ECtHR comes from the fact that its decisions are enforced voluntarily. Each time a member state party to the Convention enforces the decisions of the ECtHR issued against it, that member state behaves cooperatively. Cooperation, thus, is essential for the ECtHR's selfregulatory powers.

\section{The Academic Community}

The academic community has played an important role in promoting the work of the ECtHR and in training new generations of lawyers. Although more scientific research is needed to substantiate this point, common sense and a look at the curricula of master degree programs offered in Europe support the idea that academic circles have contributed to the ECtHR's self-regulatory quest. Academia can theoretically test the principles proposed by the ECtHR and can bring visibility to the ECtHR and its case-law by commenting on the ECtHR's work and by organizing conferences.

An exercise in imagination can further validate this argument. If the academic circles in Europe and in the rest of the world had never written about the ECtHR, had never commented on its case-law and had not provided human rights law courses, would the ECtHR have benefitted from the same reputation? The answer is probably negative.

48 ECtHR. A. Menarini Diagnostics S.R.L. v. Italy, quoted above. See for example, Waelbroeck, Denis and Sven Frisch. "Après l'Arrêt Menarini. L'impact de la Convention européenne de Sauvegarde des Droits de l'Homme et des Libertés Fondamentales sur les Procédures en Droit de la Concurrence." Scrutinizing Internal and External Dimensions of European Law. Les dimensions internes et externs du droit européen à l'épreuve. Liber Amicorum Paul Damaret, Vol. II. Eds. Inge Govaere and Dominik Hanf. Brussels: Peter Lang, 2013, pp. 663-691.

Bronckers, Marco and Anne Vallery. "EU Competition Law After The Menarini Case." MLex Magazine 3.1 (2012): pp. 44-47. 
(c) The Zeitgeist

The zeitgeist is the last external element that contributed to the ECtHR becoming a self-regulatory tribunal. Europe after wwII was a continent that focused on peace-building through democratisation, removal of tariffs and deeper commercial ties. Transactional supranationalism played a key role as states decided to trade more intensely with each other while transferring parts of their sovereign powers to supranational institutions. This process intensified after the fall of the Berlin Wall, when more states were accepted to partially trade their sovereignty for the right to belong and contribute to supranational organizations.

The ECtHR is one of the consequences of this process. In addition, the development and respect for international law has normalized the member states' cooperation with the ECtHR's.

The self-regulating nature of the ECtHR has been essential for the development and the protection of human rights in Europe and for the construction of a strong and respected ECtHR. This aspect of the ECtHR must be taken into account when analysing its impact on European competition law. 